\title{
Pragmatic Teaching Materials Based on Literature Works for Indonesian Education Students
}

\author{
Yulia Esti Katrini1, Farikah2, Mursia Ekawati3 \\ \{yuliaestikatrini@untidar.ac.id\} \\ ${ }^{1,2,3}$ Universitas Tidar, Indonesia
}

\begin{abstract}
This descriptive qualitative research examines the implications found in seni bangsa-bangsa dan Nyanyian Angsa poetry and what character values found in the poetry. Because literary works contain irrefutable linguistics that is used in speech, there are also important phenomena to identify human identity and character. The data is taken from the literary work "Nyanyian Angsa" by Rendra and "Seni Bangsa-Bangsa" by Kholil Gibran. Data is processed through agreements, classification, interpretation, analysis, and verification based on Searle, Kiefer and Bierwich (1980) and Wijana (1996). Pragmatic languages assess the meanings related to questions made using syntax, by interpreting the question is in context. Linguistic research by utilizing literary works is an interesting phenomenon considering that literature is a reflection of the lives of its people. There are various forms of speech there.
\end{abstract}

Keywords: Literary works, Poetry, and Pragmatics.

\section{INTRODUCTION}

To communicate is an essential role in daily life; it results in language use activities within the society, including among students, lecturers, staff, managers, and many other parties. One of the language use activity realizations is a speech act. Every speech act will produce speech with specific meaning based on the intention. Those are part of linguistic which is studied pragmatically, the study of language use.

The language use which is studied in pragmatics, is inseparable with context. The context itself includes social and cultural context and become a speech act user's background. As stated by Pranowo [1] that each speech in speech act always contains three things, they are (1) locutionary speech act: speech produced by the speaker, (2) illocutionary act: the meaning contained in the speech, (3) perlocutionary act: the effect of speech.

Daily life speech forms are very complex, depending on speech participants, location, time, and speech topic. Therefore, speech may involve some speech participants and situations. The language use can be viewed as a theory application for pragmatics study in the Indonesian Language Education and Literature Study Program. There are many things that can be used as the material in language use, either spoken or written. Some contexts which contain speech performers, location, time, situation, and material, can also be categorized as the language use.

The literary works which can be developed as pragmatics teaching material are works of poets like W. S Rendra, Sapardi Djoko Damono, Taufik Ismail, Kahlil Gibran. Poetry is a kind of literary work that has few words but deep meaning. As pragmatics teaching material, poetry 
can broaden the knowledge if it is well interpreted. As shown in one row of Kahlil Gibran's work "The art of the Romans is in echo)," which means The Romans always put justice and righteousness more than anything in nationhood. For them, echo is the statue of a beautiful woman who carries a scale and is named Lady of Justice. It can be said that the row implies that The Romans always put righteousness in justice. Beside poetry, there are also some novels that are full of pragmatic contexts like the works of A. Mustofa Bisri, Ahmad Tohari, Ayu Utami, and many others. The following is one of the speech act in short story anthology, Lukisan Kaligrafi (Calligraphy Painting) written by A. Mustofa Bisri:

"Kasunan? " tanyaku setengah berteriak (" Kasunan?" half-shouted I asked)

“Eee, jangan berteriak! “ Bisik Ibu. Tetapi aku sudah bergegas meninggalkannya. (" Eee, don't shout! " Mom whispered. But I’ve already rushed leaving her)

The example above shows the directive speech act of prohibiting. Directive speech acts can be ordering, asking, inviting, requesting, and many others. If the analysis based on its accordance to social purpose, Leech [2] classified speech act into four types; they are conflictive, competitive, collaborative, and convivial.

The research result shows that there are various speech acts found in literary works such as in poetry, short stories, and novels which become a part of pragmatic studies. The whole meaning of the literary works which contain character-building elements can be acquired while interpreting the speech meaning in literary works. Those are empathy, tolerance, patience, and also fundamental human nature's understanding. This emphasizes that it is possible to develop teaching materials that orient to literary works.

\section{METHOD}

This research used descriptive qualitative methods. Data collected in this study consisted of words and pictures. The stages of the research included providing other data, then analyzing data, and providing conclusions. The main instrument in this study was a human instrument. The researcher himself or the help of others is the main data collection tool. Data analysis was done through data condensation, data display, and reflection/verification images. Data condensation, presentation and interpretation would be related to the values of the rules that were applied in a society based on Miles, Huberman and Saldana's theory [3]. Analysis of the change and step-by-step development of the song and the interrelation of data were taken from the study of Rendra's "Song of the Swan" and poetry: Art of the Nations "by Khalil Gibran to obtain the complete results. Then, the data was processed through agreements, classification, interpretation, analysis, and verification based on Searle, Kiefer and Bierwich [1] and Wijana [4].

\section{RESULT AND DISCUSSION}

The research on the development of literary work-oriented pragmatics teaching materials gives a new color in the teaching field. It is because many kinds of speech acts with various contexts can be found in literary works. Between the speaker and speech partner may also have different speech situations.

The suggested teaching materials are taken from poetical literary work entitled Nyanyian Angsa (Song of The Swan) by WS. Rendra, it involves the speaker whose occupation as a 
brothel owner, people in doctor's clinic, doctor and nurse, rectory manager and priest, heaven keeper angel, with Maria Zaitun as the speech partner, along with different forms of speech. There are also various contexts and different locations. The speech act found can be classified as conflictive since there are elements of threatening, expelling, and scolding. This occurred in the brothel between the brothel owner and Maria Zaitun, as well as between the rectory manager and Maria Zaitun. Besides, there is also a collaborative speech act of reporting, notifying, explaining, telling, and giving information. Another speech act found is the convivial speech act of asking, inviting, greeting, praising, respecting and agreeing.

Similar findings also exist in poetry entitled Dongeng Marsinah (Marsinah's Tale) by Sapardi Djoko Damono. There are speech acts which involve speaker and speech partner, the speech, and context in different kinds of speech act as well.

According to pragmatics theory stated by Leech [2] a number of aspects which are often put into consideration are: (1) speaker and speech partner, (2) speech context, (3) speech purpose, (4) speech as an act or activity and (5) speech as verbal act product. Those things are mostly found in the language use of literary works, either novel or poetry. In addition, speech acts found in literary works can be pragmatically analyzed as proposed in Searle's theory [1], in which speech acts are classified into: (1) locutionary act, speech act to state something; (2) illocutionary act, speech which does not only function to state or inform something but also to do something (The act of doing something); and (3) perlocutionary act, speech act which is intended to influence the speech partner.

\section{a. Speech Acts in Literary Works}

This research acquired a data sample from a poem entitled Nyanyian Angsa (Song of The Swan) by WS Rendra, which centers on a woman named Maria Zaitun. She works as a prostitute because of her economic problem. Another poem entitled Dongeng Marsinah (Marsinah's Tale) by Sapardi Djoko Damono. It tells about Marsinah, the labor of watch factory who was later murdered by her employer because she always became the pioneer in the demonstration for labors' rights and obligations. Both poetries filled with pragmatics elements, which also provide character building through the events in that poetry.

A pragmatics analysis sample can be taken from part of speech in poetry. For example as follows.

\begin{tabular}{|l|l|}
\hline Majikan rumah pelacuran berkata & The brothel owner said to her: \\
kepadanya: & "It's been two weeks you lie down \\
“Sudah dua minggu kamu berbaring & Your illness is getting worse \\
Sakitmu makin menjadi & No more money you produced \\
Kamu tak lagi menghasilkan uang & Instead, toward me you owed \\
Malahan padaku kamu berhutang & Money kept flowing out \\
Ini biaya melulu & I couldn't withstand any longer \\
Aku tak kuat lagi & Today you must leave \\
Hari ini kamu harus pergi & (the Heaven keeper angel \\
(malaekat penjaga Firdaus & The face is resolute and envious \\
Wajahnya tegas dan dengki & With burning sword \\
Dengan pedang yang menyala & Pointed at me \\
Menuding kepadaku & Then my blood kept freezing \\
Maka darahku terus beku & Maria Zaitun is my calling \\
Maria Zaitun namaku & A whore with whole of miseries \\
\hline
\end{tabular}




\begin{tabular}{|l|l|}
\hline $\begin{array}{l}\text { Pelacur yang sengsara } \\
\text { Kurang cantik dan agak tua) }\end{array}$ & Less pretty and quite oldies) \\
\hline
\end{tabular}

Context: a dialogue between brothel owner (speaker) and Maria Zaitun (speech partner) with the purpose of expelling.

The poetry above is in accordance to pragmatics theory proposed by Leech [2] there is speaker and speech partner, there is speech context, there is speech purpose, there is speech as act or activity, and there is speech as verbal act product. In this case, the speaker is the brothel owner who said to Maria Zaitun as the speech partner. The speech purpose is to expel Maria Zaitun who did not produce money anymore (the context), and the act is to expel the speech partner and to scold her to leave at once that day. Brothel owner's speech is a verbal act product. As poetical literary work, aesthetics is the dominant component in it. There is a metaphor with the symbolization of the heaven guardian angel's cruelty, who seemed to expel Maria Zaitun with a blazing sword pointed at her, followed by Maria Zaitun's fear which is depicted in hyperbole figure of speech, Maria Zaitun's blood kept freezing.

Those figures of speech are repeated frequently by presenting the guardian angel of the heaven with the blazing swords, whose face was envious and arrogant, expelling Maria Zaitun, and disgustingly stabbed the ailing Maria's crotch with the sword. Everything is depicted as symbolically and hyperbolically as literary work. This explains that poetical literary works still maintain the poetic level using beautiful figures of speech as their main characteristic. Pragmatics analysis in the form of the speaker and speech partner in that poetry also occurred among Maria Zaitun and the people, in this case, are the patients waiting at the doctor's clinic. The conflictive speech act is shown by the verbal act: they step aside and cover their nose. This indicates an act of insulting Maria Zaitun: in the context of they did not want to be infected by her disease.

Banyak pasien lebih dulu menunggu

her)

Ia duduk di antara mereka

Tiba-tiba orang-orang menyingkir dan menutup

cover)

Hidung mereka
(Many patients waiting first before

(She sat among those)

(All of sudden, people step aside and

(Their nose)

The poem excerpt above proved the occurrence of the conflictive verbal act, which is intended to Maria Zaitun. Another speech act is the competitive speech act of ordering, commanding and asking which occurred among Maria Zaitun, doctor, and the nurse with the examination context in the doctor's examination room.

\begin{tabular}{|c|c|}
\hline $\begin{array}{l}\text { "Maria Zaitun." } \\
\text { " Utangmu sudah banyak padaku." kata } \\
\text { dokter. } \\
\text { "Ya." Jawabnya. } \\
\text { "Sekarang uangmu berapa?. } \\
\text { "Yidak ada." } \\
\text { Dokter geleng kepala dan menyuruhnya } \\
\text { telanjang } \\
\text { "Cukup." Kata dokter. } \\
\text { Dan ia tak jadi meriksa. }\end{array}$ & $\begin{array}{l}\text { "Maria Zaitun." } \\
\text { "Your debt to me is increasing." The doctor } \\
\text { said. } \\
\text { "Yes." She responded. } \\
\text { "Now how much money do you have?. } \\
\text { "Nothing." } \\
\text { The doctor shook his head and asked her to } \\
\text { remove her clothes } \\
\text { "Enough." The doctor said. } \\
\text { And he canceled the examination. }\end{array}$ \\
\hline
\end{tabular}




\begin{tabular}{|l|l|}
\hline Lalu ia berbisik kepada jururawat: & Then he whispered to the nurse: \\
" Kasih ia injeksi vitamin C." & "Inject her with vitamin C." \\
$\begin{array}{l}\text { Dengan kaget jururawat berbisik kembali: } \\
\text { "Vitamin C." }\end{array}$ & $\begin{array}{l}\text { "Vitamin C." } \\
\text { "Dokter, paling tidak ia perlu sarvasan. }\end{array}$ \\
"Untuk apa? Ia tak bisa bayar." & "Foctor, she need sarvasan at least." \\
\hline
\end{tabular}

The excerpt from the poem above is competitive speech acts that told Maria Zaitun to get naked, ordered her to cover it again, and asked the nurse to give vitamin $\mathrm{C}$ injection. In addition, competitive speech acts also appear in the poem of Dongeng Marsinah that occurred between the characters, between the narrators, the employer (figure "siapa"), and Marsinah.

\begin{tabular}{|l|l|}
\hline Marsinah, kita tahu, tak bersenjata, & Marsinah, we know, weaponless \\
Ia hanya suka merebus kata & She just likes poaching the words \\
Sampai mendidih & Effervescent \\
Lalu meluap ke mana-mana & Then overflowed everywhere \\
"Ia suka berpikir," kata siapa & "She likes to think," who said \\
"itu sangat berbahaya," & "that is so dangerous," \\
"dan haru hakekat waktu," kata siapa & "She knows the nature of time," who said \\
"ke asalnya, debu.," & "and should be returned \\
\hline
\end{tabular}

Competitive speech act occurred when the narrator was talking to figure siapa about Marsinah, and the features of the speech acts were: commenting, insinuating, giving warning and finally advocating to murder Marsinah because she is accused of becoming a provocateur that was endangering the firm where she was employed. This type of speech act is also found in the Nyanyian Angsa (Song of The Swan) song in the context of event happening in the church.

\begin{tabular}{|c|c|}
\hline 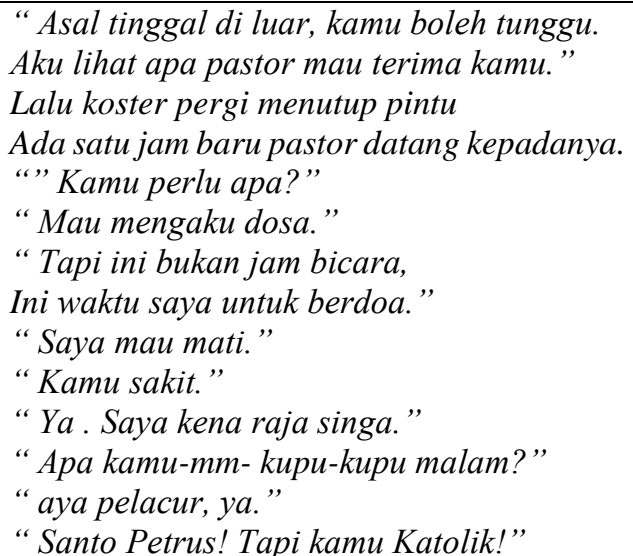 & $\begin{array}{l}\text { "If you stay outside, you might wait. } \\
\text { I will see if the pastor want to meet you." } \\
\text { Then sacristan close the door } \\
\text { Around one hour, Pastor meets him. } \\
\text { "What do you need?" } \\
\text { "I want to make a confession." } \\
\text { This is my time to pray." } \\
\text { "I wanna die." } \\
\text { "Are you ill?" } \\
\text { "Yes, suffering from syphilis." } \\
\text { "Are you -mm- streetwalker?" } \\
\text { "Prostitute, yes." } \\
\text { "Santo Petrus! But you are Catholic!" }\end{array}$ \\
\hline
\end{tabular}

The context of the speech act above is Maria Zaitun coming to church to confess, that was at first rejected by the church sacristan but was the allowed on condition. The competitive speech acts which occur include asking Maria Zaitun to wait outside the church door and telling her that it is not the schedule to talk with pastor. Then, the speech act of giving warning, protesting occurred when the priest found out that Maria Zaitun was a prostitute suffering from 
syphilis and she was a Catholic. In addition, the speech acts of asking also occurred, both by Maria Zaitun and Marsinah, as the following excerpt of poem.

\begin{tabular}{|l|l|}
\hline "Santo Petrus! Pater dengarkan saya. & "Santo Petrus! Pater listens to me. \\
Saya tak butuh tahu asal usul dosa saya & No need to know the origin of your sin, for \\
Yang nyata hidup saya gagal. & me \\
Jiwa saya kalut. & In reality, my life failed \\
Dan saya mau mati." & My soul is cluttered. \\
& And I die." \\
\hline
\end{tabular}

\begin{tabular}{|l|l|}
\hline “Saya ini Marsinah, & "I am Marsinah, \\
Buruh pabrik arloji. & Watch factory worker. \\
Ini sorga, bukan? Jangan saya diusir & It is heaven, isn't it? Don't get me kicked out \\
Ke dunia lagi; jangan saya dikirim & To the world again, don't send me \\
Ke neraka itu lagi." & In the hell again." \\
\hline
\end{tabular}

Examples of excerpts from the poem presented have exhibited competitive speech acts, but there are still several other types of speech acts that occurred in a poem such as collaborative speech acts which include asking, giving information, telling, and so on. The examples are as follows.

\begin{tabular}{|l|l}
\hline (Malaekat penjaga firdaus & (the Heaven keeper angel \\
Wajahnya jahat dan dengki & The face is resolute and envious \\
Dengan pedang yang menyala & With burning sword \\
Tak bisa apa-apa. & Cannot do anything \\
Dengan kaku ia beku. & Force being frozen \\
Tak berani lagi menuding padaku & No longer dare to point at me \\
Aku tak takut lagi.) & I am afraid once more.) \\
& \\
Semak-semak yang tak terurus & Unkempt bushes \\
Dan tak pernah ambil peduli, & And never take care, \\
Meregang waktu bersaksi: & Stretch of time to testify: \\
Marsinah & Marsinah was dragged \\
diseret & And get dumped \\
& Perfect alone \\
Dan dicampakkan & \\
Sempurna sendiri & \\
\hline
\end{tabular}

Excerpt from the poem which contains collaborative speech acts is where informing about Maria Zaitun who was no longer afraid of the guardian angel of paradise because she had been invited by her Lord to enter the heaven, as did the thickets which reported that Marsinah was being dragged, dumped until she finally died. From poetry literary works, numbers of speech acts can be used as a mean of pragmatic studies development, with different atmospheres from the studies of other language use.

\section{b. Implications of Literary Works in Pragmatics}


Literary works, especially poetry, are works that use language as a medium, where the language used is very limited, due to the demand of its form. Solid language can be interpreted through the meanings which often require extensive knowledge. For example, is the first five lines of a poem from Kahlil Gibran entitled The Art of The Nations.

\author{
The Arts of The Nations \\ The art of the Egyptians is in the occult \\ The art of the Chaldeans is in the calculation \\ The art of the Greeks is in proportion \\ The art of the Romans is in echo \\ The art of the Chinese is in etiquette
}

The first interpretation is from the title of the poem where the readers obtain broad knowledge by searching the meaning of the art of the nations. At least more than half of the world has been inventoried by Kahlil Gibran about their identities and characters. The words "the art of the Egyptians is in the occult" contain meaning that must be sought for both the literal and literary meanings. For instance, the meaning of "occult symbolizes belief in supernatural powers that can be controlled by humans. So the interpretation is made by connecting the real world with the imaginary world of the author; therefore, occult can be connected with the meaning of gods, kings, mummies, and pyramids. Through poetry literary works, implications to be used in pragmatics studies can be found.

Poetry is a form of literary work with few words but full of meaning. As a pragmatic material, a poem can expand knowledge if, in the interpretation is demanded to seek the implications of a word or sentence. One example of Kahlil Gibran's poem line, which reads "The art of the Romans is in echo" turns out to mean that the Romans prioritize justice and righteousness because echo for the Romans is a statue of a beautiful woman carrying scales which named Lady of Justice. Thus, the implication of the poem line is that the Romans upheld justice and righteousness in their lives.

This study attempts to explore the implications of poetry interpretations that can be linked with pragmatic theories about locution, illocution, and perlocution. Likewise, with the types of sentences in pragmatic studies which are direct and indirect sentences. Through teaching material developed from the implications of poetry interpretations, students at the same time also receive character education such as empathy, tolerance, patience, and also understanding the basic human natures in general.

\title{
4. CONCLUSION
}

Literary works are products of language use created by considering different issues. The use of language with specific aims and objectives is included as part of the pragmatic study requirements. Hence, the development of teaching material which orients to literary works is suitable for pragmatic learning. In addition to the use of language with the choice of words, literary works also contain useful values for character building.

The results of this study indicate that speech acts can be linked to both illocutionary studies and discourse that refer to the paradigm changes and studies on language. Hence, conflictive speech acts are found, such as threatening, expelling, urging, underestimating, and so on. In addition, competitive speech acts with social objectives are also found, such as ordering, asking, prohibiting, giving warning, criticizing, insinuating, and so on. As for the other forms of speech acts also found are collaborative speech acts which include reporting, giving information, 
explaining, telling, and so on. The last speech acts found are convivial speech acts which are in line with the social objectives such as inviting, greeting, praising, asking, and appreciating, and so on. Such speech acts are found in the literary works of poetry written by W. S Rendra and Sapardi Djoko Damono.

\section{REFERENCES}

[1] J. Searle, F. Kiefer, and M. Bierwisch, Speech Act Theory and Pragmatics. Springer Netherlands, 1980 .

[2] G. Leech, Principles of Pragmatics. London: Longman, 1993.

[3] M. B. Miles, A. M. Huberman, and J. Saldana, Qualitative Data Analysis. United States of America: SAGE, 2014.

[4] I. dewa P. Wijana, Dasar - Dasar Pragmatik. Yogyakarta: Andi, 1996. 